\title{
Fluorescent in situ hybridisation (FISH) for hemizygous deletion at the elastin locus in patients with isolated supravalvular aortic stenosis
}

Helena Fryssira, Rodger Palmer, Katherine A Hallidie-Smith, James Taylor, Dian Donnai, William Reardon

\begin{abstract}
Both Williams syndrome and isolated supravalvular aortic stenosis (SVAS) are caused by mutations at the elastin locus. Deletion demonstrable by FISH is the hallmark of Williams syndrome, whereas the mutations reported so far in SVAS have been more subtle. FISH positive elastin hemizygosity has not been reported in isolated SVAS. This report records our experience of FISH for elastin deletion in isolated SVAS and specifically reports a patient with non-Williams related SVAS, positive for the elastin deletion by FISH.
\end{abstract}

(F Med Genet 1997;34:306-308)

Keywords: FISH; elastin locus; supravalvular aortic stenosis.

Supravalvular aortic stenosis (SVAS) is a rare form of left ventricular outflow tract obstruction. It is classically associated with Williams syndrome, ${ }^{1-5}$ in which context the related clinical features of characteristic facies, mental retardation, and gregarious personality will also be observed. ${ }^{6}$ However, as recognised by McKusick, ${ }^{7}$ SVAS may also be recorded in the absence of Williams syndrome and there have been several reports documenting autosomal dominant transmission of the characteristic. ${ }^{8-10}$ Despite this distinction between isolated SVAS and Williams syndrome associated SVAS, the natural history of the abnormality appears similar in both instances. As is true of Williams syndrome, many patients with isolated SVAS may have pulmonary stenosis or stenoses of other arteries. ${ }^{911} 12$ However, in contrast with Williams syndrome, these patients have normal facial features and development. Aside from familial examples, SVAS may also be encountered as a sporadic finding in patients with no further features to suggest Williams syndrome, in which case the lesion may represent a new mutation at the locus involved in the autosomal dominant form.

The aetiological relationship between SVAS and Williams syndrome has recently become somewhat clearer. Initially familial SVAS was mapped to chromosome $7 \mathrm{q}$, near the elastin locus in two families. ${ }^{13}$ Further supportive evidence implicating elastin in the genesis of SVAS came from the report of a pedigree showing autosomal dominant transmission of SVAS associated with a $6 ; 7$ translocation, in which the translocation breakpoint on chromosome 7 was shown to disrupt the elastin gene. ${ }^{1415}$ Submicroscopic hemizygous deletions at the elastin locus have since been shown in both familial and sporadic cases of Williams syndrome. ${ }^{16}$ Importantly, these deletions appeared to encompass the whole gene and possibly extend beyond elastin. The size of the deletions is thought to exceed $250 \mathrm{~kb} .^{17}$ The greater phenotypic effects in Williams syndrome were speculated to represent either functional differences between individual mutations of elastin or deletion of adjacent loci in Williams syndrome. ${ }^{16}{ }^{17}$ Fluorescent in situ hybridisation using cosmid probes flanking either end of the elastin locus to determine hemizygosity at this locus has since been found to give a positive result in $96 \%$ of patients with classical Williams syndrome ${ }^{18}$ and these data have been corroborated from other smaller studies. ${ }^{1920}$

Two other reports have identified mutations within the elastin gene in SVAS. Ewart et $\mathrm{al}^{17}$ described a second family with deletion at the 3 ' end of the elastin gene, in the same region as that reported earlier in the family with a $6 ; 7$ translocation disrupting the elastin gene. ${ }^{15}$ Similarly, Olson $e t a l^{1}$ reported a single family with SVAS segregating, in which a deletion within the elastin locus was identified. While this deletion does disrupt the same region of the gene at the $3^{\prime}$ end, as previously reported in non-Williams related SVAS, ${ }^{15}{ }^{17}$ it also extends within the gene almost to the 5 ' end. No FISH data were presented for this case.

Although it is now clear that the molecular basis of isolated SVAS and Williams syndrome are similar, the precise basis of the phenotypic differences between these two clinically distinct situations remains a matter of conjecture. Similarly, the clinical application of these molecular advances remains quite different in respect of the two patient groups. While elastin hemizygosity has been well evaluated in Williams syndrome and is now in routine clinical use, ${ }^{18-20}$ deletions of elastin have only been published for three families with SVAS. ${ }^{15} 1721$ Morris $e t a l^{2}$ recently presented data from further studies involving two other SVAS kindreds. Evaluations included documentation of dysmorphic features, echocardiography, and psychological tests for the Williams syndrome cognitive profile (WSCP). In one family, of nine affected subjects, with a $75 \mathrm{~kb}$ deletion which disrupted the elastin gene in exon 28
Received 14 March 1996 Revised version accepted for publication 2 December 1996 
Table 1 Cardiac findings in the patients included in the report

\begin{tabular}{lllll}
\hline & \multicolumn{2}{l}{ Stenosis } & & \\
\cline { 2 - 4 } Identity & Subvalvular & Valvular & Supravalvular & mm Hg $\Delta p$ \\
\hline DC & - & - & Tubular & 121 \\
DK & No echo & Records & - & 91 \\
LD & - & - & Tubular & - \\
HG & - & - & Tubular & 67 \\
SG & - & ToR & Tubular & 96 \\
DJ & Fibromuscular ring & AoR & Ring & 80 \\
JK & No echo & Records & Mild sinotubular & 79 \\
SP & Subvalve membrane & - & Tubular & 60 \\
AP & Subvalve membrane & Restricted movement & Tur & \\
\hline
\end{tabular}

and extended 3', SVAS expression was variable; one had mental retardation, seven had the WSCP, and two had some facial characteristics of Williams syndrome. In a second family with three affected subjects sharing a $300 \mathrm{~kb}$ deletion, which included elastin as well as the $75 \mathrm{~kb}$ deleted in the first family, all had the WSCP and facial features of Williams syndrome. In the family with the $6 ; 7$ translocation disrupting elastin, ${ }^{14} 15$ none of the affected members had the WSCP. We have performed FISH studies for elastin deletions in nine patients with isolated SVAS and the purpose of this communication is to report our findings.

\section{Material and methods}

PATIENTS

Nine cases of isolated SVAS, eight sporadic and one familial, were identified through the records in the Department of Cardiology of the Great Ormond Street Hospital for Children. In all cases the diagnosis had been confirmed by echocardiography. Careful assessment for features of Williams syndrome was undertaken on all cases and this condition confidently excluded. The cardiac findings of these patients

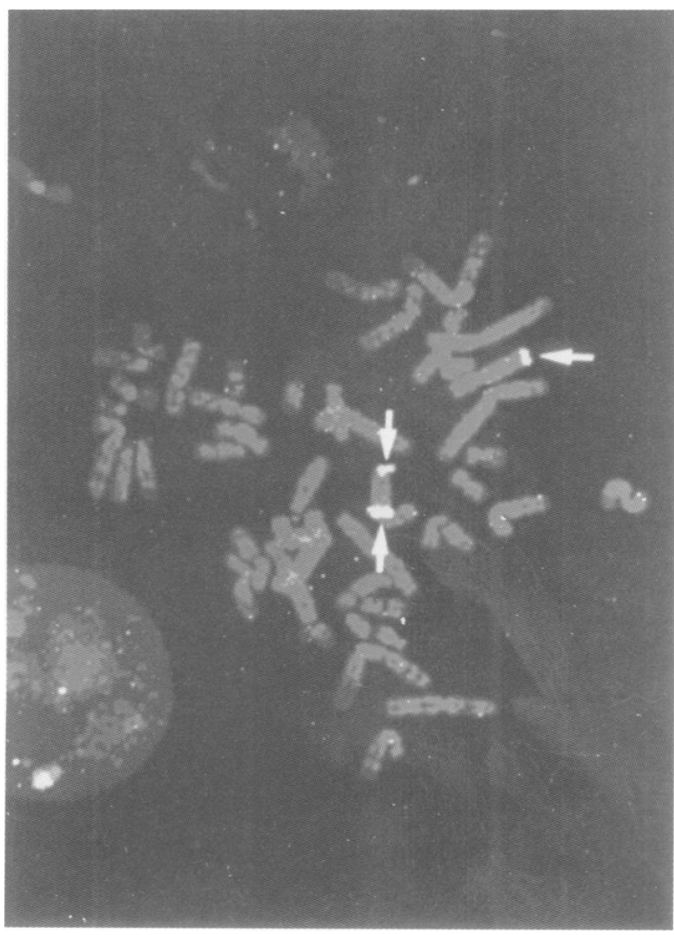

Figure 1 FISH examination of metaphase chromosomes from patient HG. The telomeric probe D7S427 has been used to identify both chromosomes 7 . There is hemizygosity at the elastin locus, using the WSCR probe containing cosmids from the $5^{\prime}$ and $3^{\prime}$ ends of the elastin gene. ${ }^{16}$ are listed in table 1 . Blood samples were obtained from patients and their parents and subjected to cytogenetic analysis.

\section{CYTOGENETIC STUDIES}

Metaphase chromosomes from peripheral blood cultures were examined by $\mathrm{G}$ banding for each patient. To evaluate hemizygosity at the elastin locus, FISH was performed on metaphase chromosomes cultured from peripheral blood using the commercial probe WSCR (Oncor Inc, Gaithersburg) containing cosmids from the $5^{\prime}$ and $3^{\prime}$ ends of the elastin gene. ${ }^{16}$ The telomeric probe D75427 was used as a marker for chromosome 7 and also as a control. Ten cells were counted per patient.

\section{Results}

One of the nine cases evaluated (HG) was found to be deleted for elastin by FISH (fig 1). Parental samples from this boy were analysed and two signals were observed from the elastin probes in each parent, indicating that the patient represents a de novo deletion event.

\section{CLINICAL REPORT}

HG, now aged 16 years, is the second child of healthy, non-consanguineous parents. The pregnancy and birth history are unremarkable. A heart murmur was first investigated aged 4 years and marked supravalvular aortic stenosis was identified. The pressure gradient estimated by Doppler echocardiography indicated a pressure drop of $67 \mathrm{~mm} \mathrm{Hg}$ above the aortic valve and cross sectional echocardiography showed a moderate degree of left ventricular hypertrophy as well as the supravalvular narrowing. Cardiac catheterisation confirmed that there was no gradient between the body of the left ventricle and the immediate supra-aortic valve region, but there was a distinct pressure gradient between the immediate supravalvular area and the arch of the aorta. Angiocardiography confirmed a normal left ventricular outlet and aortic valve. There was an area of tubular narrowing of the ascending aorta, from the sinotubular junction almost to the origin of the innominate artery, at which point the aorta was of normal dimension and the origin of the innominate carotid and left subclavian artery was normal. No other aortic abnormality or origin stenosis of other arteries was noted. Corrective surgery was undertaken at the age of 7 years. The patient has enjoyed normal development, attends normal school, and has none of the stigmata of Williams syndrome (fig 2).

\section{Discussion}

Hemizygosity at the elastin locus has been shown to be highly sensitive in confirming mutation at this locus in patients with Williams syndrome. While the involvement of elastin mutation in isolated SVAS is indisputable, the nature of the relationship between SVAS and Williams syndrome in terms of mutational basis is less clear. It has been speculated that Williams syndrome may represent a more extensive deletion of the elastin locus, incorporating adjacent genes and thereby accounting for the additional phenotypic characteristics. ${ }^{15} 17$ 


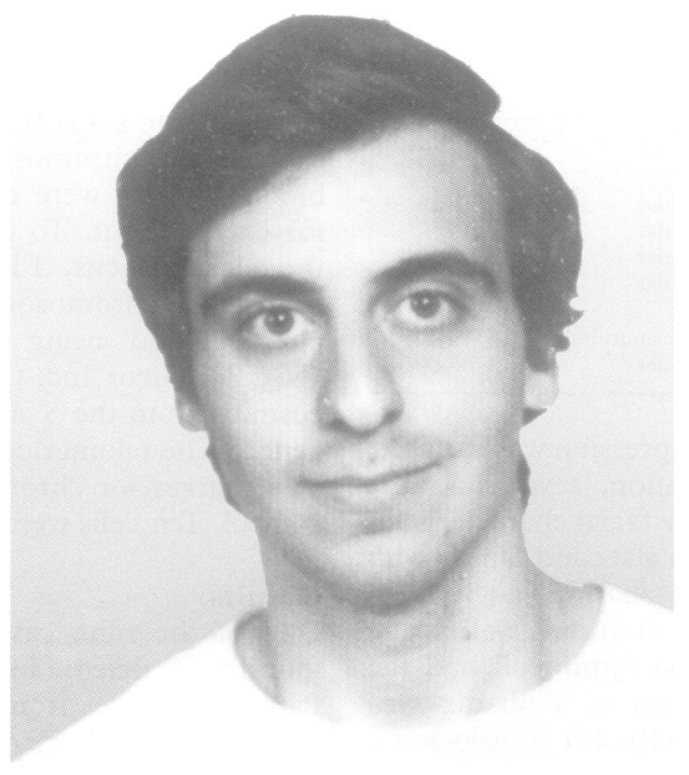

Figure 2 Patient HG. Note the absence of characteristic facial features of Williams syndrome. (Photograph reproduced with permission.)

There is recent evidence to support this idea with the report that LIM-kinase is also deleted in all 20 Williams syndrome cases tested. ${ }^{23}$ Morris et $a l^{22}$ have shown that some deletional mutations in SVAS families may be associated with some, but not all, features of Williams syndrome. Unlike the two situations reported by Morris et al, ${ }^{22}$ Olson et all identified a family with a deletion confined to the elastin gene and extending throughout the gene from the $5^{\prime}$ end. This observation would imply that at least a proportion of cases with isolated SVAS should be amenable to identification by FISH using cosmids which flank the 5' and 3' ends of the elastin locus. The patient we describe confirms this but the observation that eight other cases have normal FISH tests for elastin suggests that FISH diagnosis of elastin mutations in SVAS cases will apply to only a minority of such patients.

The observation we report is also useful in terms of how the SVAS and Williams phenotypes might be related to mutational events in elastin. Up to now, it has been thought that the SVAS related elastin mutations are likely to result in qualitative or quantitative changes in elastin mRNA synthesis and have a direct bearing on the manner in which this gene is expressed. However, the identification of absent FISH signals, signifying deletion of both 5 and 3 ' ends of the elastin gene in our case of isolated SVAS, may prompt a re-evaluation of this tentative conclusion. Further molecular studies are in progress on this patient.

Dr Katherine Halladie-Smith died in September 1995, just as the work reported in this paper was being completed.

Williams JCP, Barratt-Boyes BG, Lowe JB. Supravalvula aortic stenosis. Circulation 1961;24:1311-18.

2 Beuren AJ, Opitz J, Harmjanz D. Supravalvular aortic stenosis in association with mental retardation and certain facial appearance. Circulation 1962;26:1235-40.

3 Black JA, Bonham-Carter RE. Association between aortic stenosis and facies of severe infantile hypercalcaemia. Lan cet 1963;ii: $745-8$.

4 Halladie-Smith KA, Karas S. Cardiac anomalies in Williams-Beuren syndrome. Arch Dis Child 1988;63:809 13.

5 Winter RM, Baraitser M. London dysmorphology database. Oxford: Oxford Medical Publications, 1995.

6 Gorlin RJ, Cohen MM Jr, Levin LS. Syndromes of the head and neck. 3rd ed Oxford Mon No 19. Oxford: Oxford University Press, 1990.

7 McKusick VA. Mendelian inheritance in man. 11 th ed. Baltimore: Johns Hopkins University Press, 1994

8 Eisenberg R, Young D, Jacobson B, Boito A. Familia supravalvular aortic stenosis. Am f Dis Child 1964;108:341

9 Chiarella F, Dagna Bricarelli FD, Lupi G, et al. Familia supravalvular aortic stenosis: a genetic study. f Med Genet 1989;26:86-92.

10 Schmidt MA, Ensing GJ, Michels VV, et al. Autosoma dominant supravalvular aortic stenosis: large threegeneration family. Am $\mathcal{F}$ Med Genet 1989;32:384-9.

11 Ino $\mathrm{T}$, Nishimoto $\mathrm{K}$, Iwahara $\mathrm{M}$, et al. Progressive vascula lesions in Williams-Beuren syndrome. Pediatr Cardiol 1988; 9:55-8

12 Martin EC, Moseley IF. Supravalvular aortic stenosis. $B$ Heart $\mathcal{f}$ 1973;35:758-65.

13 Ewart AK, Morris CA, Ensing GJ, et al. A human vascula disorder, supravalvular aortic stenosis, maps to chromosome 7. Proc Natl Acad Sci USA 1993;90:3226-30.

14 Morris CA, Loker J, Ensing G, Stock AD. Supravalvula aortic stenosis cosegregates with a familial 6;7 translocation which disrupts the elastin gene. Am f Med Genet 1993 46:737-44.

15 Curran ME, Atkinson DL, Ewart AK, et al. The elastin gen is disrupted by a translocation associated with supravalvular aortic stenosis. Cell 1993;73:159-68.

16 Ewart AK, Morris CA, Atkinson D, et al. Hemizygosity at the elastin locus in a developmental disorder, Williams syndrome. Nat Genet 1993;5:11-16.

17 Ewart AK, Jin W, Atkinson D, et al. Supravalvular aortic stenosis associated with a deletion disrupting the elastin gene. $\mathcal{F}$ Clin Invest 1994;93:1071-7.

18 Lowery MC, Morris CA, Ewart AK, et al. Strong correlatio of elastin deletions, detected by FISH, with William syndrome: evaluation of 235 patients. Am $\mathcal{F}$ Hum Genet 1995;57:49-53.

19 Borg I, Delhanty JDA, Baraitser M. Detection of hemizygosity at the elastin locus by FISH analysis as a diagnostic tes in both classical and atypical cases of Williams syndrome. $f$ Med Genet 1995;32:692-6.

20 Kotzot D, Bernasconi F, Brecevic L, et al. Phenotype of the Williams-Beuren syndrome associated with hemizygosity at the elastin locus. Eur $\mathcal{F}$ Pediatr 1995;154:477-82.

21 Olson TM, Michels VV, Urban Z, et al. A $30 \mathrm{~kb}$ deletion within the elastin gene results in familial supravalvular aortic stenosis. Hum Mol Genet 1995;4:1677-9.

22 Morris CA, Mervis CB, Bertrand J, et al. Lumping vs splitting in Williams syndrome: supravalvular aortic stenos families with a phenotype overlapping WS. XVI David W Smith workshop on malformations and morphogenesis, Big Sky, Montana, August 1995.

23 Tassabehii M, Metcalfe K, Fergusson WD, et al. LIM-kinase deleted in Williams syndrome. Nat Genet 1996;13:272-3. 